\title{
Analysis of the performance rate variations of schools contemplated with the School Cistern Program in the valleys of Jequitinhonha and Mucuri
}

\author{
Análise das variações na taxa de rendimento das escolas contempladas pelo Programa Cisternas \\ nas Escolas nos vales do Jequitinhonha e do Mucuri
}

Análisis de las variaciones en el rendimento de las escuelas incluídas por el Programa Cisternas em

Escuelas em los vales Jequitinhonha y Mucuri

Received: 06/23/2021 | Reviewed: 06/28/2021 | Accept: 07/01/2021 | Published: 07/14/2021

\author{
Agnaldo Keiti Higuchi \\ ORCID: https://orcid.org/0000-0001-8719-6154 \\ Universidade Federal dos Vales do Jequitinhonha e Mucuri, Brazil \\ E-mail: agnaldo.higuchi@ufvjm.edu.br \\ Nathalia Stockler Fialho Soares \\ ORCID: https://orcid.org/0000-0002-9667-3060 \\ Universidade Federal dos Vales do Jequitinhonha e Mucuri, Brazil \\ E-mail: nathaliastockler17@hotmail.com \\ Fernanda Aparecida Guedes Honorato da Silva \\ ORCID: https://orcid.org/0000-0002-0784-5474 \\ Universidade Federal dos Vales do Jequitinhonha e Mucuri, Brazil \\ E-mail: faghs.nanda@gmail.com \\ Naldeir dos Santos Vieira \\ ORCID: https://orcid.org/0000-0001-5624-8345 \\ Universidade Federal dos Vales do Jequitinhonha e Mucuri, Brazil \\ E-mail: naldeir.vieira@ufvjm.edu.br \\ Jemima Esteves Jardim \\ ORCID: https://orcid.org/0000-0003-3707-839X \\ Universidade Federal dos Vales do Jequitinhonha e Mucuri, Brazil \\ E-mail: jemimaesteves@hotmail.com
}

\begin{abstract}
The aim of the study was to analyze the variations in students' performance rates in schools int the Jequitinhonha and Mucuri Valleys, in the Brazilian state of Minas Gerais, contemplated by the School Cistern Program. The survey of the schools contemplated by the Program was carried out with documental research of spreadsheets provided by the Brazilian Semi-arid Articulation. The data about school failure and dropout rates were collected from the Instituto Anísio Teixeira (INEP), and made available on the Qedu website. The non-parametric Wilcoxon test was used for testing averages. As means of school performance rates in the periods before and after the installation of the cistern in schools, they were not different. Thus, the expectation of an improvement in school performance rates through the Program was not evident. Thus, the present study shows that there are factors that still need to be studied and treated for the School Cistern Program to reach its objective of improving school performance rates in the region of the Jequitinhonha and Mucuri valleys.
\end{abstract}

Keywords: School cistern program; School performance; Semi-arid; Jequitinhonha and Mucuri Valleys.

\begin{abstract}
Resumo
O objetivo deste estudo foi analisar as variações ocorridas nas taxas de rendimento dos alunos das escolas dos Vales do Jequitinhonha Mucuri, estado de brasileiro de Minas Gerais, contempladas pelo Programa Cisternas nas Escolas. O levantamento das escolas contempladas no Programa foi realizado por meio de pesquisa documental em planilhas disponibilizadas pela Articulação do Semiárido Brasileiro. Os dados sobre reprovação e abandono em cada escola foram coletados do Instituto Anísio Teixeira (INEP), estando estes disponibilizados no site Qedu. Foi utilizado o teste não paramétrico de Wilcoxon para os testes de média. As médias das taxas de rendimento escolar dos períodos anterior e posterior à instalação da cisterna nas escolas não foram diferentes. Por isso, a expectativa de uma melhora na taxa de rendimento das escolas por meio do Programa não se mostrou evidente. Assim, o presente estudo mostra que há fatores que ainda precisam ser estudados e tratados para que o Programa Cisterna nas Escolas consiga atingir seu objetivo de melhorar a taxa de rendimento nas escolas da região dos vales do Jequitinhonha e do Mucuri.
\end{abstract}

Palavras-chave: Programa cisterna nas escolas; Rendimento escolar; Semiárido; Vales do Jequitinhonha e Mucuri. 


\section{Resumen}

El objetivo de este estudio fue analizar las variaciones en las tasas de desempeño de los estudiantes de las escuelas de los valles de Jequitinhonha Mucuri, en el estado brasileño de Minas Gerais, cubiertos por el Programa Cisternas en las Escuelas. La encuesta de las escuelas cubiertas por el Programa se llevó a cabo mediante la investigación documental en hojas de cálculo proporcionadas por el Articulação do Semiárido Brasileiro. Los datos sobre reprobación y deserción en cada escuela se obtuvieron del Instituto Anísio Teixeira (INEP), que está disponible en el sitio web de Qedu. Se utilizó la prueba no paramétrica de Wilcoxon para las pruebas de medias. Las tasas de rendimiento escolar promedio para los períodos antes y después de la instalación de la cisterna en las escuelas no fueron diferentes. Por lo tanto, la expectativa de una mejora en la tasa de desempeño de las escuelas a través del Programa no fue evidente. Así, este estudio muestra que existen factores que aún deben ser estudiados y abordados para que el Programa Cisterna nas Escolas pueda lograr su objetivo de mejorar la tasa de desempeño en las escuelas de la región de los valles de Jequitinhonha y Mucuri.

Palabras clave: Programa cisterna en las escuelas; Rendimiento escolar; Semi árido; Valles de Jequitinhonha y Mucuri.

\section{Introduction}

Since water is an essential resource for life on Earth, one of the challenges of the 21 st century is related to managing hydric resources. All human and environmental activities depend on water and its scarcity greatly impacts people's lives. Thus, the right to clean and safe water was recognized as an essential human right in order to fully enjoy life and other rights, as water is crucial to life improvement (Organização das Nações Unidas, 2010).

Despite being a fundamental human right, 2.2 billion people do not have access to safe drinking water (Unicef, United Nations Children's Fund \& WHO, World Health Organization, 2019). According to data from the "Brazilian Institute of Geography and Statistics" (Instituto Brasileiro de Geografia e Estatística, 2010), in Brazilian rural areas only 32.7\% of households are linked to the water supply network.

Water scarcity is even more common in the Brazilian semi-arid region, where precipitation is irregular and intense rainfall happens in short periods. Such precipitation irregularity has become a main factor in the economic and social reality of the region which has the worst social indicators in education, health, child mortality, and illiteracy, compromising even more the socio-economic and political environment, marked with wealth and power concentration, especially in the rural area (Lira, et al., 2011). For example, the illiteracy rate of the Brazilian semi-arid in 2010 was three times higher than the national rate and its GPD per capita was three times smaller (Mata \& Resende, 2018).

Therefore, the construction of social technologies to capture and store rainwater is an important social, environmental and economic instrument in arid and semi-arid regions in the world. Systems can collect water from roofs and store it in cisterns which are small individual reservoirs. The cistern is applied in dry areas where water from the rainy season is accumulated for the dry season, guaranteeing water mainly for drinking.

In this context, in 1999 a non-governmental organization (NGO) was created called the Articulação do Semiárido Brazilieiro (ASA - Brazilian Semi-arid Articulation), which was an essential point for the creation of the Programa um Milhão de Cisternas Rurais (P1MC - One Million Rural Cisterns Program) two years later. The objective was to reach rural families of the semi-arid area by constructing cement cisterns. With the Program, numerous advances took place not only for the families but for the whole rural community, such as increased school frequency, a decrease of illnesses from contaminated water, and a decrease in women's workload in household chores.

Another important experience was the extension of the Program to build cisterns in collective spaces like schools, especially those located in rural communities not attended by urban water networks. This subprogram, called "School Cisterns" (Cisternas nas Escolas), used 52-thousand-litter cisterns as a social technology to store rainwater in schools. The cistern allows the school community to consume quality water throughout the year without interrupting its activities due to lack of water.

With this in context, the present article aims to analyze the variations in students' performance rates in schools contemplated by the School Cistern Program. The performance rates refer to reaching the academic and frequency requirements 
by the end of the school year, which are the pass, failure, and drop-out rates. Drop-out occurs when the student stops going to class during the school year. It is understood as a student who stopped attending or failed the school year and did not enroll in the following year to continue studying (Fundação Lemann, 2020).

In order to do this, schools were selected from municipalities in the region of the Jequitinhonha and Mucuri Valleys, Minas Gerais State, and were contemplated by the Program between 2015 and 2018 through the partnership of ASA and the Ministério do Desenvolvimento Social (MDS - Ministry of Social Development).

\section{The Brazilian semi-arid}

The Brazilian semi-arid region is marked by a deficit of hydric resources (Araújo, 2012), arid climate, unpredictable rainfalls, large variability between rainfalls in time and space, and soil poor in organic material (Robertson, et al., 2014; Sietz, 2014; Marengo, et al., 2016). As to precipitation, the rainy season takes place from four to six months of the year, yet rainfall is unequal and low, which is related to low soil retention and high evaporation levels (Dombroski, et al., 2011; Lopes, et al., 2012).

Precipitation in the region is characterized by rainfall concentrated in short intervals. It is common for a single month to have total precipitation superior than $70 \%$ of the region's average (Andrade, et al., 2010). Besides these characteristics, the precipitation shows seasonal patterns, with a rainy season concentrated in three to four months, though it may extend to six months (Guerreiro, et al., 2013). In most of the semi-arid region, sporadic rain is the only source of water for survival since the geological origin of the soil is crystalline, with low underground water accumulation (Ribeiro \& Oliveira, 2019).

Thus, the semi-arid region is marked by irregular rains, with short periods of intense rain and long periods of drought, and shallow soil, which impedes water storage. It is located in most of the Northeast of Brazil, reaching the northern part of Minas Gerais (Dietrich, 2019). The Brazilian semi-arid has a territorial extension of 982,563.3 $\mathrm{km}^{2}$. The current delimitation of the region is in Resolutions No. 107 from July 17th, 2017 and No. 115 from November 23rd, 2017 from the Ministério de Integração Nacional (Ministry of National Integration). With this update, 73 municipalities were included from the states of Bahia, Ceará, Maranhão, Minas Gerais, Pernambuco, Piauí, and Paraíba, totaling 1262 municipalities where 27 million Brazilians live (Brasil, 2017).

To be considered part of the semi-arid area, the municipalities of the Northeast and Southeast regions must meet at least one of the criteria: average annual precipitation equal or inferior to 800 milimeters, aridity level equal or inferior to 0.5 , and drought risk equal or superior to 60\%, considering every day of the year (Brasil, 2017).

In Minas Gerais, the semi-arid region is understood as the North of Minas and Jequitinhonha Valley, where 1,492,198 million people live in 91 municipalities and $121,259 \mathrm{~km}^{2}$ (Sudene, 2018).

In the face of this low precipitation, the Brazilian semi-arid region has hydric resource problems which largely hamper satisfactory access and use of water (Souza et al., 2016). With the depletion of habitual sources and intermittence of water-ways, families turn to using non-habitual sources, many times shared with animals, compromising their quality (Souza, et al., 2016).

In this adverse context and with the necessity of living in the semi-arid, decentralized technologies have been developed as a result of experiences and knowledge of capturing and storing rainwater, sustainable management of the caatinga, alternative production technologies, food sovereignty, contextualized education, among others (Morais, et al., 2017).

The development of decentralized water supply structures, managed by a family or community, has been an important strategy to guarantee access to quality water, mainly to the rural population because it involves implementation and maintenance costs substantially lower than the construction necessary to connect this population to water supply networks (Santana \& Arsky, 2016).

In the semi-arid, social technologies represent a range of simple and innovative practices developed by the sertaneja (rural) population to live with dignity. This range of experiences involves techniques to capture and store water, feed storage for 
animals, food storage for humans, solar distillers, biodigester septic tanks, and sustainable management of the earth and existing hydric resources (Andrade, et al., 2010; Ventura, et al., 2012; Souza, et al, 2016; Sousa, et al., 2017).

Among the social technologies to coexist with the semi-arid, one of the most relevant is the cistern, which has increased visibility, through implementation of public policies, due to its capacity to solve drought problems effectively and to generate transformation and social inclusion (Dias, 2013; Jesus \& Costa, 2013). In the next section, the use of cisterns in the semi-arid region is contextualized; a social technology also spread by the School Cistern Program.

\section{The School Cistern Program}

According to Ventura et al. (2012), one of the milestones brought by the view of coexisting with the semi-arid happened with the constitution of the Articulação do Semiárido (ASA) in 1999, resulting from the articulation of about 50 nongovernmental organizations. In the place of large hydraulic works, which are responsible for unequal water supply to rural populations, ASA started proposing the implementation of small infrastructure which decentralize the means of capturing and storing rainwater, such as underground reservoirs, cisterns, and stone tanks (Neves, et al., 2010), with the environmental question being fundamental in formulating these technologies.

The initial mark of the Cisterns Program was the Conference of Parties of the United Nations Convention to Combat Desertification and Drought (COP-3), which happened in 1999 in Olinda, Pernambuco (Santana \& Arsky, 2016). Parallel to the COP-3, a forum of Non-profit Civil Society Organizations (OSCs) that are present in the semi-arid region was held (Moraes, 2011). In this forum, various organizations which worked with cisterns in the project discovered that their articulation had become systemic, permanent, and could have political interference (Costa \& Dias, 2013).

As a result of the Forum parallel to COP-3, ASA was founded and the group of organizations that would compose it articulated themselves around the perspective of coexistence with the Semi-arid. Moreover, an experimental project to test technologies to collect and store water was proposed to the government. The experimental project began in 2000 with resources from the Ministério do Meio Ambiente (MMA - Ministry of the Environment) and would be the beginning of the Cistern Program. The three lines of action of the project were: a) systematization of various cistern experiences which were in development at the time of ASA's creation; b) construction of about 500 experimental cisterns; c) drafting of a broader project to continue the actions (Costa \& Dias, 2013).

The systematizations and experimental units created in the first project legitimized and proved cistern efficiency in guaranteeing quality and enough water for a family. Moreover, it allowed a greater approximation between ASA technical staff and employees from the Agência Nacional das Águas (ANA - National Water Agency), facilitating the negotiation of the second project (Costa \& Dias, 2013). In this second project, the ANA financed the construction of 12,400 cisterns. The program was expected to be implemented in five years, with a total cost of 424.3 million dollars (Fonseca, 2012; Santos \& Borja, 2020).

With the advance of partnerships between ASA and public and private organizations, some of the technologies proposed by ASA became programs, as is the case of plate cisterns to capture rainwater for human supply, within the One Million Cisterns Program (P1MC), also known as the Cisterns Program (Sousa, et al, 2017).

In the P1MC, the ASA had a relevant role in building the agenda, formulating policies, and implementing the Program's actions. This articulation enabled negotiation, cooperation, and conflict management together with communities and the State (Costa \& Dias, 2013). The influence of Civil Society Organizations (OSCs) through the ASA has been an extremely relevant factor, guaranteeing the necessary synergy for sustainable continuation of the Program.

As well as the cisterns for families, there are also important experiences constructing cisterns in collective spaces, mainly cisterns in rural schools that are not attended by urban water supply networks. By involving educators, students, and families, Brito et al. (2012) considers the School as an efficient environment to teach and execute programs that aim to improve 
education and health. Since students are learning, they become multipliers and important agents in influencing and disseminating new social technologies. In the school context, as well as cisterns for water supply, cisterns for production may also be built. These aim to store water for the production of fruits and vegetables, improving food quality for students.

The lack of water in schools has been one of the factors that influence its operations. Giving attention to this fact and after debates from UNICEF, the ASA extended the program for building individual cisterns to the school context. The Pilot Project was developed in 2009 with the support of MDS and the state government of Bahia, whose objective was to provide water supply to schools of the Brazilian semi-arid. After 2010 the initiative expanded, under the coordination of the ASA and partnered with the MDS through the Secretária Nacional de Segurança Alimentar e Nutricional (SESAN - The National Secretariat for Food Security and Nutrition), Instituto Brasileiro de Desenvolvimento e Sustentabilidade (IABS - Brazilian Institute of Development and Sustainability), and Agência Espanhola de Cooperação Internacional para o Desenvolvimento (Aecid - Spanish Agency for International Development Cooperation) (Dietrich, 2019).

The program aims to guarantee quality water for rural schools of the Semi-arid through the implementation of a social technology: 52-thousand-litter school cisterns (Asa, 2020). According to SESAN, the action intends to provide water supply for school consumption and food preparation, directly benefiting students, teachers, and other rural public school staff, improving life quality of the school community and providing better teaching/learning conditions (Dietrich, 2019).

Currently the Program covers schools from the nine states of the Semi-arid (PE, PB, AL, SE, BA, CE, RN, PI, and MG) which do not have access to water and have been mapped by the Federal Government. This list includes schools that are located in indigenous villages and quilombo communities, which should be prioritized (Asa, 2020).

Beside water access, another relevant question for the Program is the quality of this scarce resource. It is known that the negative effects of infections such as diarrhea, parasitosis, and dehydration, mostly from poor drinking water, sanitation, and hygiene, directly affect learning performance and cognitive learning in the long term (Gottfried, 2010).

Rodrigues (2014) investigated, by using xMAP technology, the prevalence of Cryptosporidium sp, Giardia lamblia and Entamoeba histolytica in children of three cities of the Brazilian semi-arid and the main epidemiological factors of these enteroparasites. It was concluded that there were predominantly monoparasites in $93.5 \%$ of the infected children, evidently associating factors such as family income, home sewage type, water treatment before drinking and use, and the prevalence of the protozoa in the studied population.

According to Guerrant et al. (2013), diarrheal incidences in early childhood limit growth by $8 \mathrm{~cm}$ and cause an IQ reduction in children at age 7 or 8 . About $75 \%$ of school absences are justified by such illnesses, as reported by Lau et al. (2012).

Some authors state the importance of water access in schools to children's cognitive performance, mainly for short-term memory exercises (Bar-David, et al., 2005; Benton \& Burgess, 2009; Fadda, et al., 2012). Ortiz-Correa et al. (2016) found the positive and significant effects of schooling, where children who live in houses with indoor plumbing complete 0.7 school years more than those without it. Garn et al. (2013) found an increase in the number of middle school enrollments associated to an increase of new water sources.

Dietrich (2019) considers that the construction of cisterns may interfere directly with students' school performance, since this technology prevents school closure due to lack of water. A school with little or no access to water ends up reducing school-day hours, with class presence directly and consistently affecting student performance (Menezes-Filho, 2007). With the objective of analyzing if this effect also occurs in the schools in the Jequitinhonha and Mucuri Valleys, the present study adopted the following methodological procedures. 


\section{Methodological Procedures}

The present research may be classified as descriptive in relation to its objectives and quantitative concerning the data approach. Descriptive research finds and evaluates the relationships between variables as they spontaneously manifest themselves in facts, situations and conditions that already exist. Despite the basis obtained through bibliographic research, considering the approach, type and data collection instruments, the data source was predominantly documentary. (Köche, 2011).

Data collection occurred in two moments. In the first, documental research of material provided by the Ministério da Cidadania (Ministry of Citizenship) and the ASA addressed the research field and time period of the analysis. The research field involved schools from the municipalities of the Jequitinhonha and Mucuri Valley Regions, Minas Gerais state, which built rainwater collection and storage systems through the School Cistern Program.

Regarding the time period of analysis, it was verified, in the mapping stage, that cisterns were built in schools in the study field from 2015 to 2020. However, the data from the School Census provided by the Instituto Nacional de Estudos e Pesquisas Educacionais Anísio Teixeira (INEP - National Institute of Educational Studies and Research Anísio Teixeira) covers the period up to 2018, making it possible to analyze only the schools where the cisterns were built between 2015 and 2017, allowing for the analysis of data made available in the years before and after the construction of the technology.

Research conducted in March 2020 showed that, according to information from the ASA and the Ministério da Cidadania, 110 rural schools from 17 municipalities received cisterns in the selected years. Respectively in 2015, 2016, and 2017, 40, 49, and 21 cisterns were built. The following Table 1 shows the researched municipalities and the quantity of schools in each one.

Table 1: Municipalities surveyed and number of schools with cisterns in each municipality by the year 2017.

\begin{tabular}{cc}
\hline Muicipality & $\begin{array}{c}\text { No. of contemplated } \\
\text { schools }\end{array}$ \\
\hline Almenara & 17 \\
Chapada do Norte & 15 \\
Padre Paraíso & 14 \\
Joaíma & 10 \\
Itinga & 9 \\
Jequitinhonha & 9 \\
Pedra Azul & 9 \\
Santa Helena de Minas & 5 \\
Divisópolis & 4 \\
Araçuaí & 3 \\
Berilo & 3 \\
Bertópolis & 3 \\
Jordânia & 3 \\
Felisburgo & 2 \\
Ladainha & 2 \\
Rubim & 1 \\
Teófilo Otoni & 1 \\
\hline Total & 110 \\
\hline
\end{tabular}

Source: Authors (2020).

In the second moment of the data collection, the performance rates of the 110 schools were collected, according to the completion year of the cistern construction, in the years before and after that, together with the documents provided by the INEP, at https://qedu.org.br. The data, collected on May 30, 2020, refer to the percentage of early elementary school students failing and dropping out and were provided by their municipal and state public schools.

These percentages to calculate performance were chosen, against indexes like the Índice de Desenvolvimento da 
Educação Básica (the Basic Education Development Index - IDEB, because they are available. Since many schools are municipal and did not participate in the Prova Brasil (Brazil Test) in the analyzed period, there is no IDEB related information for them.

The collected data was tabled on an Excel spreadsheet, in which percentual variations of each performance index were calculated. Next, normality tests were made on each variable to determine the adequate average test, using the statistics package SPSS. The Kolmogorov-Smirnov and Shapiro-Wilk tests were used. The criterion for testing the null hypothesis (data follow normal distribution) was $\alpha=0.05$, i.e., significance above 0.05 indicates adherence to normal distribution.

The results of the normality tests of each variable are exposed in the following Chart 1 :

Chart 1: Results of the Normality test.

\begin{tabular}{|l|c|c|c|c|c|c|c|}
\hline \multirow{2}{*}{ Variable } & \multicolumn{3}{|c|}{ Kolmogorov-Smirnov } & \multicolumn{3}{c|}{ Shapiro-Wilk } & \multirow{2}{*}{ Normality } \\
\cline { 2 - 7 } & Statistics & $\mathrm{df}$ & $\mathrm{Sig}$ & Statistics & $\mathrm{df}$ & Sig & No \\
\hline Previous failures & .473 & 110 & .000 & .277 & 110 & .000 & \multirow{2}{*}{ No } \\
\hline $\begin{array}{l}\text { Posterior } \\
\text { failures }\end{array}$ & .458 & 110 & .000 & .420 & 110 & .000 & No \\
\hline $\begin{array}{l}\text { Previous } \\
\text { dropouts }\end{array}$ & .494 & 110 & .000 & .388 & 110 & .000 & No \\
\hline $\begin{array}{l}\text { Posterior } \\
\text { dropouts }\end{array}$ & .513 & 110 & .000 & .325 & 110 & .000 & \multicolumn{2}{c}{} \\
\hline
\end{tabular}

Source: Authors (2020).

Since the data do not follow normal distribution, the use of non-parametric tests is indicated (Dancey \& Reidy, 2006). Thus, the Wilcoxon paired test was chosen and to interpret the results $\alpha=0.05$ was used as the criterion to reject the null hypothesis. This value is widely accepted and used in the Applied Social Sciences area (Hair Junior et al., 2005). After the rejection or not of the null hypothesis, the differences of the averages may or may not be considered, indicating the possible effect of the implementation of the School Cistern Program in the Basic Education performance rates of the researched municipalities.

\section{Result Analysis}

\subsection{Analysis of the performance rate before and after the construction of cisterns in schools by municipality}

In relation to failure rates, the biggest variation in the schools' averages was in Almenara, with an increase of $8.6 \%$ in the studied period. However, the municipality of Chapada do Norte showed the largest reduction: $-1.8 \%$.

It was observed that in many municipalities like Berilo, Bertópolis, and Itinga there was no variation in the failure rate, since in these cities no-one failed (passing rate of $100 \%$ of the early elementary school students). Table 2 exposes the variations of each municipality. 
Table 2: Variation in the percentage of disapproval in each municipality.

\begin{tabular}{cc}
\hline Municipality & Failure variation (\%) \\
\hline Chapada do Norte & -1.813 \\
Divisópolis & -0.675 \\
Pedra Azul & -0.200 \\
Joaíma & -0.110 \\
Berilo & 0.000 \\
Bertópolis & 0.000 \\
Itinga & 0.000 \\
Jequitinhonha & 0.000 \\
Jordânia & 0.000 \\
Ladainha & 0.000 \\
Santa Helena de Minas & 0.000 \\
Teófilo Otoni & 0.000 \\
Padre Paraíso & 0.621 \\
Rubim & 1.300 \\
Araçuaí & 2.767 \\
Felisburgo & 8.350 \\
Almenara & 8.606 \\
\hline
\end{tabular}

Source: Authors (2020).

In relation to the variation in dropout, that is, the percentage of students who begin the school year, but no longer attend classes, the city of Felisburgo (which showed an increase in failure rate of $8.35 \%$ ) presented the largest reduction of $-2.550 \%$. The municipality of Jordan, on the other hand, presented an increase of $2.367 \%$ in dropouts. The variations of dropout rates in each municipality are shown in Table 3, below:

Table 3: Variation in the dropout percentage in each municipality.

\begin{tabular}{cc}
\hline Municipality & Failure variation (\%) \\
\hline Felisburgo & -2.550 \\
Padre Paraíso & -2.107 \\
Pedra Azul & -0.744 \\
Divisópolis & -0.675 \\
Araçuaí & 0.000 \\
Berilo & 0.000 \\
Bertópolis & 0.000 \\
Itinga & 0.000 \\
Ladainha & 0.000 \\
Rubim & 0.000 \\
Santa Helena de Minas & 0.000 \\
Teófilo Otoni & 0.000 \\
Almenara & 0.047 \\
Chapada do Norte & 0.173 \\
Jequitinhonha & 0.233 \\
Joaíma & 0.550 \\
Jordânia & 2.367
\end{tabular}

Source: Authors (2020). 
As the variations show, it can be concluded that there was a decrease in dropout in four cities, in eight cities there was no variation, and in five dropouts increased.

\subsection{Analysis of the averages of failure and dropout rates of schools before and after the implementation of the cisterns in each school}

In order to verify whether the averages of the 110 schools researched before and after the Cisterna Program in Schools can be considered equal or not, Wilcoxon's non-parametric test was performed.

Regarding the failure rate, Table 4 below illustrates the results of the paired test.

Table 4: Wilcoxon test result for two paired samples for failure rate.

\begin{tabular}{lc}
\hline & Posterior failures - previous failures \\
\hline $\mathrm{Z}$ & -1.925 \\
\hline Asymp. Sig. (bi-caudal) & .054 \\
\hline
\end{tabular}

Source: Authors (2020).

The result of the test indicates that the average failure rates in the schools studied in the year after the implantation of the cisterns cannot be considered different than that of the year before, since significance was $>0.05$. It can be considered, then, that after the construction of the cistern the average failure rates remained statistically equal. This result, however, does not indicate that the construction of the cistern did not indirectly influence the failure rate in the schools contemplated. As it will be seen in the limitations of the study, the type of analysis adopted does not allow a direct inference of cause and effect between the construction of the cistern and the variation in the performance rate.

Regarding dropouts, Table 5 below illustrates the test result.

Table 5: Wilcoxon test result for two paired samples for dropout rate.

\begin{tabular}{lc}
\hline & Posterior dropouts - previous dropouts \\
\hline $\mathrm{Z}$ & -.973 \\
\hline Asymp. Sig. (bi-caudal) & .330 \\
\hline & Source: Authors (2020).
\end{tabular}

The result of the average dropout test indicates that there was no rate change in the period before and after the construction of the cistern in the schools studied, with a significance of $>0.05$. In short, in the schools studied, after the construction of the cisterns, it is not possible to consider statistically that there was a variation in the failure and dropout rates, showing that the benefits expected by the Program have not yet occurred.

Such results do not repeat what was found in Dietrich's study (2019), which identified that the program increases the probability of students completing the first cycle of elementary school (5th grade), when evaluating the impact of the School Cistern Program in the Brazilian semi-arid region on educational results. The results found by Dietrich suggest that, in the short term, there is an increase of $0.82 \%$ in the 1 st grade approval rate for schools exposed to the program for 2 years, while the program decreases the 5 th grade dropout rate by $0.33 \%$. 


\subsection{Analysis of school failure and dropout averages per year of construction.}

After analyzing the results for the year 2015 and data in tables 6 and 7, it can be noted that the average failure and dropout rates were not different, because both tests showed significance $>0.05$.

Table 6: Wilcoxon test result for failure rate in 2015.

\begin{tabular}{lc}
\hline & Posterior failures - previous failures \\
\hline $\mathrm{Z}$ & -1.069 \\
\hline Asymp. Sig. (bi-caudal) & .285 \\
\hline & Source: Authors (2020).
\end{tabular}

Table 7: Wilcoxon test result for dropout rate in 2015

\begin{tabular}{cc}
\hline & Posterior dropouts - previous dropouts \\
\hline $\mathrm{Z}$ & .000 \\
\hline Asymp. Sig. (bi-caudal) & 1.000 \\
\hline
\end{tabular}

Source: Authors (2020).

Thus, from the results obtained, it cannot be said that the averages were different, indicating that the construction of the cisterns in 2015 did not affect the performance rates.

With respect to the year 2016, the results also show that the failure and dropout rates remained the same. Tables 8 and 9 below illustrate the results of the average tests.

Table 8: Wilcoxon test result for failure rate in 2016.

\begin{tabular}{lc}
\hline & Posterior failures - previous failures \\
\hline $\mathrm{Z}$ & -1.752 \\
\hline Asymp. Sig. (bi-caudal) & .080 \\
\hline
\end{tabular}

Source: Authors (2020).

Table 9: Wilcoxon test result for dropout rate in 2016.

\begin{tabular}{lc}
\hline & Posterior dropouts - previous dropouts \\
\hline$Z$ & -.420 \\
\hline Asymp. Sig. (bi-caudal) & .674 \\
\hline
\end{tabular}

Source: Authors (2020).

As observed above, in 2016 both tests presented significance $>0.05$, so it can be considered that the averages of the rates are statistically equal in the period.

Finally, in the year 2017 the failure rate average remained statistically equal, while the dropout average was reduced. Tables 10 and 11 illustrate the results. 
Table 10: Wilcoxon test result for failure rate in 2017.

\begin{tabular}{lc}
\hline & Posterior failures - previous failures \\
\hline $\mathrm{Z}$ & -.415 \\
\hline Asymp. Sig. (bi-caudal) & .678 \\
\hline
\end{tabular}

Source: Authors (2020)

Table 11: Wilcoxon test result for dropout rate in 2017

\begin{tabular}{lc}
\hline & Posterior dropouts - previous dropouts \\
\hline $\mathrm{Z}$ & -2.205 \\
\hline Asymp. Sig. (bi-caudal) & .027 \\
\hline
\end{tabular}

Source: Authors (2020).

The data for the year 2017 refer mostly to the municipality of Padre Paraíso (14 schools) and also seven schools in the municipality of Chapada do Norte. In these schools it can be verified that statistically there was a reduction in the dropout rate, because there is significance $<0.05$, indicating that possibly the Cisterna Program accomplished one of the planned developments that year.

\section{Final Considerations}

This study aimed to analyze the variations in performance rates of schools located in the semi-arid region of the State of Minas Gerais, specifically in the Jequitinhonha and Mucuri Valleys, in periods before and after participation in the School Cistern Program, a social technology implemented as public policy. After the selection of the research subjects, data collection and analysis, it was verified that, considering the whole period and all the cities, there was no statistical difference in the average performance rates.

Analyzing the periods per year, the results also showed that there was no statistical difference in the averages for failure and dropout rates except in 2017, when there was an improvement in dropout rates, especially in the cities of Padre Paraíso and Chapada do Norte. This lack of direct cistern impact on performance rates, especially dropout, was understood in the qualitative and in-depth study conducted by Vieira et al. (2020), who identified that, in general, the frequent lack of water in the period before the construction of the cisterns in rural schools did not impact the dropout of students, given the absence of alternatives for students to transfer to other neighboring or urban schools. In addition, as much as interruption of school operations may have impacted student learning, this fact may not have been reflected in the percentage of passing students, given the automatic passing policy adopted by many public schools in the region.

Despite being short term, the results do not reflect the expectations of the School Cistern Program of improving student performance rates. The presence of cisterns can be considered an improvement in the basic infrastructure of schools, which, with greater availability of water, began to offer better learning conditions, even though they were not reflected in their performance rates.

As a limitation of the study, it is recognized that, in order to analyze possible effects of the Cisterns Program in Schools, it would be relevant to analyze two groups of homogeneous schools, in equivalent environments, with the only difference being whether or not they participate in the program. Thus, it would be guaranteed that the only altered variable would be the presence of the cistern and all the differences in the results could be attributed to it. However, no such situation was found. There were no homogeneous schools that did not participate in the Program. Therefore, we opted for the paired averages test, where the failure 
and dropout rates in the initial years of elementary school were measured before treatment (installation of the cistern) and after treatment. The limitation occurs due to the presence of strange variables, such as the participation of the student's family in the Bolsa Família Program, or other changes in the school infrastructure, which could influence the index values and could not undergo treatment for their elimination.

Nevertheless, the information obtained can be used for comparisons among other socioeconomic indicators, which can lead to factors that more directly influence dropout and failure rates, such as migration to larger cities in search of work (by parents), and automatic passing, which could hide the influence of cistern installation on student performance.

Since this study paves the way for new analyses about the influence of social technologies applied by public policies, such as the School Cistern Program, on the different aspects that make up the school environment, a qualitative study is suggested, where other perspectives are raised and can complete the understanding of the Program's repercussions in the schools of the studied municipalities.

These qualitative studies will allow the analysis of the perception of the stakeholders responsible for implementing the Program, as well as the beneficiaries. Thus, in-depth information could be obtained about other results obtained by the Program that may be related to the improvement in the quality of life of students and the entire school community. Quantitative surveys can also be carried out by applying questionnaires to representatives of schools covered by the Program, with a view to evaluating the results obtained with the Program and the conservation status of the cisterns.

\section{Acknowledgments}

The authors thank the Conselho Nacional de Desenvolvimento Científico e Tecnológico (CNPq - National Council for Scientific and Technological Development) and the Ministério da Cidadania (Ministry of Citizenship) for financing this study.

\section{References}

Andrade, E. M., Meireles, A. C., \& Palácio, H. A. Q. (2010). O semiárido cearense e suas águas. In E. M. Andrade, O. J. Pereira, \& F. E. R. Dantas (Org.), O Semiárido e o manejo dos recursos naturais. (pp. 56-80). Fortaleza: Imprensa Universitária - UFC.

Araújo, J. C. (2012). Recursos hídricos em regiões semiáridas. In H. R. Gheyi (Org.), Recursos hídricos em regiões semiáridas: Estudos e aplicações. INSA; UFRB.

Asa. (2020). Ações - Cisternas nas Escolas. https://www.asabrasil.org.br/acoes/cisternas-nas-escolas\&gt

Asa. (2020). Sobre nós: Ações-P1MC. R http://www.asabrasil.org.br

Bar-David, Y., Urkin, J., \& Kozminsky, E. (2005). The effect of voluntary dehydration on cognitive functions of elementary school children. Acta paediatrica, 94(11), 1667-1673. 10.1080/08035250500254670

Benton, D., \& Burgess, N. (2009). The effect of the consumption of water on the memory and attention of children. Appetite, 53(1), 143-146. 10.1016/j.appet.2009.05.006

Brasil. (2017). Resolução No 115, de 23 de novembro de 2017. Estabelece critérios técnicos e científicos para a delimitação do Semiárido Brasileiro e procedimentos para a revisão de sua abrangência.

Brito, L. T., Azevedo, S. G., \& Araújo, J. O. (2012). Escolas Rurais Produzem Hortaliças e Frutas Utilizando Água de Chuva Armazenada em Cisterna: Estudo de caso. Anais do VIII Simpósio Brasileiro de Captação e Manejo de Água de Chuva.

Costa, A. B., \& Dias, R. B. (2013). Estado e sociedade civil na implantação de políticas de cisternas. In A. B. Costa (Org.), Tecnologia social e políticas públicas. Instituo Pólis.

Dancey, C. P., \& Reidy, J. (2006). Estatística sem matemática para psicologia. Artmed.

Dias, R. B. (2013). Tecnologia social e desenvolvimento local: Reflexões a partir da análise do Programa Um Milhão de Cisternas. Revista Brasileira de Desenvolvimento Regional, 1(2), 173-189. 10.7867/2317-5443.2013v1n2p173-189

Dietrich, T. P. (2019). Acesso à Água e Resultados Educacionais: Evidências para o semiárido brasileiro [Dissertação de Mestrado em Economia Aplicada]. Universidade Federal de Pelotas - Programa de Pós-Graduação em Organizações e Mercados. 
Dombroski, J. L. D., et al. (2011). Water relations of Caatinga trees in the dry season. South African Journal of Botany, 77(2), 430-434. 10.1016/j.sajb.2010.11.001

Fadda, R., et al. (2012). Effects of drinking supplementary water at school on cognitive performance in children. Appetite, 59, 730-737. 10.1016/j.appet.2012.07.005

Fonseca, J. E. (2012). Implantação de Cisternas para Armazenamento de Água de Chuva e seus Impactos na Saúde Infantil: Um estudo de Caso em Berilo e Chapada do Norte, Minas Gerais [Dissertação de Mestrado]. Programa de Pós-graduação em Saneamento, Meio Ambiente e Recursos Hídricos da Universidade Federal de Minas Gerais.

Fundação Lemann. (2020). Censo Escolar: Taxa de Rendimento. https://academia.qedu.org.br/censo-escolar/taxa-de-rendimento

Garn, J. V., et al. (2013). A cluster-randomized trial assessing the impact of school water, sanitation and hygiene improvements on pupil enrolment and gender parity in enrolment. Journal of Water, Sanitation and Hygiene for Development, 3, 592-601. doi: 10.2166/washdev.2013.217

Gottfried, M. A. (2010). Evaluating the relationship between student attendance and achievement in urban elementary and middle schools: An instrumental variables approach. American Educational Research Journal, 47(2), 434-465. doi: 10.3102/0002831209350494

Guerrant, R. L., et al. (2013). The impoverished gut-A triple burden of diarrhoea, stunting and chronic disease. Nature reviews Gastroenterology \& hepatology, 10(4), 220-229. doi: 10.1038/nrgastro.2012.239

Guerreiro, M. J. S., et al. (2013). Long-term variation of precipitation indices in Ceará State, Northeast Brazil. International Journal of Climatology, 33(14), 2929-2939. doi: $10.1002 /$ joc.3645

Hair Junior, J. F., Anderson, R., Tatham, R., \& Black, W. (2005). Análise multivariada de dados (5nd ed). Bookman.

Instituto Brasileiro de Geografia e Estatística. (2010). Primeiros resultados 2010. http://www.ibge.gov.br/home/estatistica/populacao/censo201 0/default_sinopse.shtm

Jesus, V. M. B., \& Costa, A. B. (2013). Tecnologia social: Breve referencial teórico e experiências ilustrativas. In A. B. Costa (Org.), Tecnologia social e políticas públicas. São Paulo: Instituo Pólis.

Köche, J. C. (2011). Fundamentos de metodologia científica: teoria da ciência e iniciação à pesquisa. Vozes.

Lau, C. H., et al. (2012). Hand hygiene instruction decreases illness-related absenteeism in elementary schools: A prospective cohort study. BMC pediatrics, 12(1), article n. 52. 10.1186/1471-2431-12-52

Lira, P. G. R., et al. (2011). P1MC e resiliência: Um estudo no município de Soledade-PB. Anais da 5 Jornada Internacional de Políticas Públicas, São Luís.

Lopes, C. G. R., et al. (2012). Forest succession and distance from preserved patches in the Brazilian semiarid region. Forest Ecology and Management, 271, 115-123. doi: $10.1016 /$ j.foreco.2012.01.043

Marengo, J. A., Cunha, A. P., \& Alves, L. M. (2016). A seca de 2012-15 no semiárido do Nordeste do Brasil no contexto histórico. Climanálise, 3, 49-54.

Mata, D. D., \& Resende, D. (2018). Changing the climate for banking: The economic effects of credit in a climate-vulnerable area. SSRN. 149. $10.2139 / \mathrm{ssrn} .3279027$

Menezes-Filho, N. A. (2007). Os determinantes do desempenho escolar do Brasil. São Paulo: Instituto Futuro Brasil, Ibmec-SP / FEA-USP.

Moraes, A. F. J. (2011). Genered Waters: The participation of womem on the program 'One Million Cisterns' in the Brazilian semi-arid region [Tese Doutorado]. Faculty of the Graduate School. University of Missouri.

Morais, H. A. R., Paiva, J. A., \& Souza, W. J. (2017). Avaliação do Programa Um Milhão de Cisternas Rurais (P1MC): Eficácia, Eficiência e Efetividade nos Territórios do Rio Grande do Norte (2003/2015). Revista de Políticas Públicas, 21(1), 133-158. 10.18764/2178-2865.v21n1p133-158

Neves, R. S., et al. (2010). Programa Um Milhão de Cisternas: Guardando água para semear vida e colher cidadania. Revista Agriculturas: experiências em agroecologia, 7(3), 7-11.

Organização das Nações Unidas. (2010). Comentário Geral no 15 do Comitê de Direitos Econômicos, Sociais e Culturais. https://www.un.org/ga/search/view_doc.asp?symbol=A/RES/64/292\&referer=/english/\&Lang=S

Ortiz-Correa, J. S., Filho, M. R., \& Dinar, A. (2016). Impact of access to water and sanitation services on educational attainment. Water Resources and Economics, 14, 31-43. d10.1016/j.wre.2015.11.002

Ribeiro, C. S., \& Oliveira, G. C. (2019). A questão hídrica no semiárido baiano: Conflitos pelo uso da água e as tecnologias sociais de aproveitamento de água de chuva. Revista del CESLA, 23.

Robertson, A. W., Baethgen, W., Block, P., et al. (2014). Climate risk management for water in semi-arid regions. Earth Perspectives, 1(12). 10.1186/2194$6434-1-12$

Rodrigues, R. N. (2014). Perfil epidemiológico e prevalência de Cryptosporidium sp., Entamoeba histolytica e Giardia lamblia em crianças com e sem diarreia no semiárido brasileiro [Monografia (Graduação)]. Universidade Federal do Ceará, Centro de Ciências, Departamento de Bioquímica e Biologia Molecular, Curso de Biotecnologia.

Santana, V. L., \& Arsky, I. C. (2016). Aprendizado e Inovação no Desenho de Regras para a Implementação de Políticas Públicas: A Experiência do Programa Cisternas. Rev. Serv. Público, 67(2), 203-226. 10.21874/rsp.v67i2.559 
Research, Society and Development, v. 10, n. 8, e37910817496, 2021

(CC BY 4.0) | ISSN 2525-3409 | DOI: http://dx.doi.org/10.33448/rsd-v10i8.17496

Santos, J. E. S., \& Borja, P. C. (2020). Captação e armazenamento de água de chuva para consumo humano no semiárido baiano no âmbito do P1MC: uma análise da viabilidade do uso da tecnologia no município de Abaré-BA. Brazilian Journal of Development, 6(1), 5259-5300. 10.34117/bjdv6n1-383

Sietz, D. (2014). Regionalisation of global insights into dryland vulnerability: Better reflecting smallholders' vulnerability in Northeast Brazil. Global Environmental Change, 25, 173-185. 10.1016/j.gloenvcha.2014.01.010

Sousa, A. B., et al. (2017). Tecnologias Sociais de convivência com o Semiárido na região do Cariri cearense. Cadernos de Ciência \& Tecnologia, 197-220. 10.35977/0104-1096.cct2017.v34.26327

Souza, N. G. de M., et al. (2016). Tecnologias Sociais Voltadas para o Desenvolvimento do Semiárido Brasileiro. Biofarm, 12 (3).

Sudene. (2018). Nova delimitação Semiárido. Retrieved April 22, 2020, from http://antigo.sudene.gov.br/delimitacao-do-semiarido

Unicef, United Nations Children's Fund, \& Who, World Health Organization. (2019). Progress on household drinking water, sanitation and hygiene I 20002017. https://www.who.int/water_sanitation_health/publications/jmp-2019-full-report.pdf?ua=1

Ventura, A. C., Garcia, L. F., \& Andrade, J. C. S. (2012). Tecnologias sociais: As organizações não governamentais no enfrentamento das mudanças climáticas e na promoção de desenvolvimento humano. Cadernos EBAPE, 10(3), 605-629.

Vieira, N. S. et al. (2020). Análise dos Resultados do Programa Cisternas nas Escolas nos Vales do Jequitinhonha e do Mucuri. UFVJM/MC/CNPq. 